\title{
PEMBEBANAN MUT'AH DAN NAFKAH 'IDDAH PADA PERKARA CERAI TALAK DENGAN PUTUSAN VERSTEK
}

\author{
Devi Yulianti, R. Agus Abikusna, Akhmad Shodikin \\ Fakultas Syari'ah dan Ekonomi Islam \\ Institut Agama Islam Negeri Syekh Nurjati Cirebon \\ Jl. Perjuangan By Pass Sunyaragi Cirebon \\ Email: ydevi075@gmail.com, a.abikusna@gmail.com, shodikin73@gmail.com
}

\begin{abstract}
Abstrak
Dalam pengajuan permohonan cerai talak di Pengadilan Agama Kuningan banyak dalam petitum permohonan yang diajukan oleh suami hanya sebatas untuk memutuskan perkawinannya tanpa disertai kewajibannya berupa pemberian mut'ah dan nafkah 'iddah terhadap istri. Selain itu ada beberapa istri juga tidak pernah mengahidiri pesidangan, sehingga perkaranya diputus secara verstek. Penelitian bertujuan ini adalah untuk mengetahui pertimbangan para hakim mengenai pembebanan mut'ah dan nafkah 'iddah pada perkara cerai talak dengan putusan verstek dan untuk mengetahui relevansi pembebanan mut'ah dan nafkah'iddah dalam perkara cerai talak dengan putusan verstek studi putusan No.1436/Pdt.G/2019/PA.Kng apabila ditinjau dari Pasal 178 ayat (3) HIR. Penelitian ini menggunakan metode penelitian kualitatif, dengan jenis penelitian yang dipakai adalah field research, dengan menggunakan beberapa metode seperti observasi, wawancara, serta menemukan fakta-fakta di lapangan terkait dengan penelitian ini. Pertimbangan hakim dalam membebankan mut'ah dan nafkah 'iddah adalah: a) secara yuridis dilihat dari Undangundang No 1 Tahun 1974 tentang Perkawinan, Kompilasi Hukukum Islam, dan Peraturan Mahkamah Agung Republik Indonesia; b) berdasarkan Dalil al-Qur'an kewajiban suami memberikan mut'ah dan nafkah 'iddah kepada mantan istri istriny; c) berdasarkan keadaan social para pihak. Mengenai Relevansi pembebanan mut'ah dan nafkah 'iddah pada perkara cerai talak dengan putusan verstek studi putusan No.1436/Pdt.G/2019/PA.Kng apabila ditinjau dari pasal 178 ayat (3) HIR yaitu dianggap tidak bertentangan sepanjang hal-hal yang diminta hakim masih berkaitan erat dengan perkara yang ditangani, selain itu, dalam perkara ini hakim memiliki kebebasan untuk menggunakan hak nya yaitu hak ex-officio hakim.
\end{abstract}

Kata Kunci: Mut'ah, Nafkah 'Iddah, Cerai Talak, Putusan Verstek 


\begin{abstract}
Abstrack
In filing applications for divorce for divorce at the Kuningan Religious Court, many of the petitum requests submitted by the husband are limited to terminating their marriage without being accompanied by their obligations in the form of giving mut'ah and 'iddah' living to the wife. In addition, there are some wives who have never attended trial, so the case is decided verstekally. This research aims to determine the judges 'considerations regarding the imposition of mut'ah and livelihoods of' iddah in the case of divorce talak with the verstek decision and to find out the relevance of the imposition of mut'ah and livelihood'iddah in divorce case with the verstek decision of study verdict No.1436 / Pdt.G / 2019 / PA.Kng when viewed from Article 178 paragraph (3) of the HIR. This research uses qualitative research methods, with the type of research used is field research, using several methods such as observation, interviews, and finding facts in the field related to this research. The judge's consideration in imposing mut'ah and living 'iddah is: a) juridically viewed from Law No. 1 of 1974 concerning Marriage, Compilation of Islamic Law, and Regulations of the Supreme Court of the Republic of Indonesia. b) based on Dalil al-Qur'an, the husband's obligation to give mut'ah and livelihood of 'iddah to his ex-wife. c) based on the social circumstances of the parties. Regarding the relevance of mut'ah infliction and livelihood of iddah in divorce case with the verstek decision of study verdict No.1436 / Pdt.G / 2019 / PA.Kng when viewed from paragraph 178 verse (3) HIR, it is not considered to be contradictory as long as the matters requested by the judge are still closely related to the case being handled, in addition, in this case the judge has the freedom to use his rights, namely the ex-officio right of the judge.
\end{abstract}

Keywords: Mut'ah, Livelihood of 'Iddah, Divorce, Verstek Decision. 


\section{A. PENDAhULUAN}

Tujuan perkawinan begitu mulia yaitu untuk membentuk keluarga bahagia, kekal, abadi berdasarkan Ketuhanan Yang Maha Esa, karena itu perlu diatur hak dan kewajiban antara masing-masing suami dan istri tersebut. Apabila hak dan kewajiban terpenuhi, maka terwujudlah keluarga yang sakinah, mawaddah, dan rahmah. Sebaliknya apabila hak dan kewajiban tidak berjalan dengan seimbang dalam membina rumah tangga pertengkaran seringkali terjadi yang mengakibatkan putusnya suatu perkawinan. Putusnya perkawinan istilah hukum yang digunakan untuk menjelaskan perceraian atau berakhirnya suatu hubungan antara seorang laki-laki dan perempuan dalam sebuah pernikahan. ${ }^{1}$ Menurut Pasal 117 KHI bahwa talak adalah ikrar suami di hadapan sidang Pengadilan Agama yang menjadi salah satu sebab putusnya perkawinan. Dalam KHI mensyaratkan bahwa ikrar suami untuk bercerai (talak) harus disampaikan di hadapan sidang Pengadilan Agama. ${ }^{2}$

Setelah terjadinya perceraian di antara suami dan istri maka ada masa menunggu atau yang lebih dikenal dengan 'iddah bagi seorang perempuan. Selain mempunyai kewajiban untuk menjalani masa 'iddah, seorang istri yang telah diceraikan oleh suaminya memiliki hak. Hak-hak tersebut diantaranya ialah mendapatkan mut'ah dan nafkah 'iddah.

Pengadilan Agama dalam menangani suatu perkara sebelum hari persidangan tiba akan memanggil para pihak yang bersangkutan agar hadir di persidangan. Dan setelah dilakukan

1 Amir Syarifuddin, Hukum Perkawinan Islam di Indonesia, (Jakarta: Prenada Media, 2006), 189.

2 Amiur Nuruddin dan Azhari Akmal Tarigan, Hukum Perdata Islam di Indonesia (Studi Kritis Perkembangan Hukum Islam dan Fiqih, UU No 1/1974 sampai KHI),..., 221. pemanggilan ada kemungkinan pada hari sidang yang telah ditetapkan tergugat tidak datang dan tidak pula mengirimkan wakilnya menghadap persidangan, sekalipun sudah dipanggil dengan patut oleh juru sita. Kalau tergugat tidak datang setelah dipanggil dengan patut, maka gugatan dikabulkan dengan putusan di luar hadir atau verstek. ${ }^{3}$

Dalam praktik hukum acara perdata, di lingkungan peradilan agama, hakim karena jabatan fungsional memiliki hak khusus dalam menyelesaikan kewenangan hakim berdasarkan jabatannya untuk melaksanakan suatu putusan, namun hakim dalam mengadili semua bagian gugatan, dilarang memberikan putusan yang tidak diminta atau melebihi yang diminta, hal tersebut sesuai dengan pasal 189 ayat (3) RBg dan pasal 178 HIR ayat (3), yang berbunyi: "Hakim dilarang menjatuhkan putusan atas hal-hal yang tidak diminta atau mengabulkan lebih dari yang digugat". ${ }^{4}$ Dari ketentuan pasal tersebut maka seorang hakim tidak boleh memutuskan pemberian nafkah 'iddah, hadhanah, mut'ah dan madhiyah jika tidak ada dalam permohonannya.

Hakim dalam memeriksa, mengadili, dan memutuskan perkara perdata harus mematuhi asas-asas yang berlaku dalam hukum acara perdata umum. Diantaranya adalah asas ultra petitum pertium, yaitu larangan bagi hakim untuk mengabulkan melebihi dari tuntutan yang dikemukakan dalam gugatan. Hakim yang mengabulkan lebih dari posita maupun petitum gugat, dianggap telah melampaui batas wewenang atau ultra vires yaitu bertindak di luar batas kewenangannya. Hal ini digariskan pada Pasal 178 ayat (3)

${ }^{3}$ Sudikno Mertokusumo, Hukum Acara Perdata Indonesia, (Yogyakarta: Liberty, 1988), 79.

R. Suesilo, RIB/HIR dengan Penjelasan, (Politea: Bogor), 131. 
HIR, Pasal 189 ayat (3) RBg. Sehingga apabila dalam suatu putusan terdapat ultra petitum (mengabulkan lebih daripada yang diminta), maka putusan itu harus dinyatakan cacat (invalid) meskipun hal itu dilakukan hakim dengan itikad baik (good faith) maupun sesuai dengan kepentingan umum (public interest) dan dapat dikategorikan sebagai tindakan yang tidak sah (ilegal). ${ }^{5}$

Seperti halnya yang terjadi di Pengadilan Agama Kuningan, yaitu perkara cerai talak yang mana selama masa persidangan tidak pernah dihadiri oleh pihak termohon, sehingga perkaranya diputus secara verstek. Akan tetapi, faktanya dalam perkara seperti ini ada beberapa hakim yang meminta kepada pemohon atau suami untuk memberikan mut'ah dan nafkah 'iddah kepada istri karena telah menceraikannya, padahal pihak termohon atau istri tidak pernah menuntut hak-haknya di persidangan. Yang kemudian oleh majelis hakim pembebanan mut'ah dan nafkah 'iddah ini dituangkan dalam sebuah amar putusan. Hal ini menjadi menarik untuk dibahas, karena dalam perkara seperti diatas hakim dianggap memberi putusan yang melebihi apa yang dimintakan oleh pemohon pada perkara cerai talak dengan putusan verstek.

\section{B. PENELITIAN TERDAHULU}

Terdapat beberapa literatur Penelitian yang berkaitan dengan judul di atas. Penelitian tersebut diantaranya, yaitu pertama, Penelitian pada tahun 2018 yang ditulis oleh Ade Ilma Maulana mahasiswa UIN Alauddin Makassar, Fakultas Syari'ah dan Hukum Jurusan Peradilan, dengan judul Penelitian "Pemberian Nafkah 'Iddah Dan Mut'ah Pada Perkara Cerai Talak Di Pengadilan Agama Sungguminasa Kelas 1B". fokus kajiannya dalam penelitian ini yaitu

5 M. Yahya Harahap, Hukum Acara
Perdata tentang Gugatan, Persidangan,
Penyitaan, Pembuktian, dan Putusan Pengadilan
(Jakarta: Sinar Grafika, 2017), 893.

dalam memutuskan pemberian nafkah 'iddah dan mut'ah pada perkara cerai talak dikarenakan adanya gugatan balik/rekonvensi dari isteri yang menuntut nafkah iddah dan mut'ah dan dikabulkan oleh majelis hakim dengan mempertimbangkan pekerjaan suami yang dianggap mampu. ${ }^{6}$

Kedua, Penelitian pada tahun 2018 yang ditulis oleh Muhlifa Nur Pradhika, mahasiswa IAIN Salatiga Fakultas Syari'ah Jurusan Hukum Keluarga Islam, dengan judul Penelitian "Penetapan Kadar Nafkah 'Iddah Dan Mut'ah Oleh Hakim Pada Cerai Talak Di Pengadilan Agama Salatiga (Studi Putusan Cerai Talak Tahun 2017)". Penelitian ini menjelaskan tentang penetapan kadar nafkah 'iddah dan mu'tah dari beberapa hasil putusan Pengadilan Agama Salatiga yang didalamnya ada gugatan balik/rekonvensi dari isteri, namun jika bentuk putusannya verstek maka tidak terdapat penetapan kadar nafkah 'iddah dan mut'ah. ${ }^{7}$

Ketiga, Penelitian pada tahun 2019 yang ditulis oleh An Nisa Primasari, mahasiswa UIN Maulana Malik Ibrahim Malang, Fakultas Syari'ah Jurusan Ahwal Al Syakhshiyyah, dengan judul Penelitian "Putusan Hakim Pengadilan Agama Nganjuk Atas Kewajiban Nafkah Yang Harus dipenuhi Suami Pada Cerai Talak (Studi Analisis Perkara No. 1839/Pdt.G/1015/PA.Ng)". Penelitian ini menjelaskan tentang termohon yang mengajukan gugatan rekonvensi atas nafkah 'iddah, mut'ah dan nafkah hadhanah, dan nafkah madhiyah. Dan yang dikabulkan majelis hakim hanya

${ }^{6}$ Ade Ilma Maulana, "Pemberian Nafkah 'Iddah Dan Mut'ah Pada Perkara Cerai Talak Di Pengadilan Agama Sungguminasa Kelas 1B." (Penelitian, Fakultas Syari'ah dan Hukum UIN Alauddin Makassar), 2018.

7 Muhlifa Nur Pradhika, "Penetapan Kadar Nafkah 'Iddah Dan Mut'ah Oleh Hakim Pada Cerai Talak Di Pengadilan Agama Salatiga (Studi Putusan Cerai Talak Tahun 2017).'( Penelitian, Fakultas Syari'ah IAIN Salatiga), 2018. 
nafkah hadhanah dan mut'ah dengan mempertimbangkan duduk perkaranya dimana pihak termohon telah nusyuz sehingga nafkah 'iddah dan madhiyah tidak dikabulkan dikarenakan isteri nusyuz serta dilihat dari penghasilan pemohon. ${ }^{8}$

Keempat, jurnal pada tahun 2017 yang ditulis oleh Syaiful Annas yang berjudul "Masa Pembayaran Beban Nafkah Iddah Dan Mut'ah Dalam Perkara Cerai Talak (Sebuah Implementasi Hukum Acara di Pengadilan Agama)". Jurnal ini menjelaskan tentang praktek pembebanan nafkah 'iddah dan mut'ah di Pengadilan Agama serta aspek yang mendasari penentuan masa pembayaran nafkah 'iddah dan mut'ah.'

Kelima, Jurnal pada tahun 2019 yang ditulis oleh Muhammad Aqwam Thariq mahasiswa UIN Maulana Malik Ibrahim Malang, dengan jurnal yang berjudul "Hak Ex Officio Hakim: Pertimbangan Hukum Hakim terhadap Pembebanan Nafkah Iddah dan Mut'ah dalam Perkara Cerai Talak Verstek Perspektif Maqashid Syariah (Kasus di Pengadilan Agama Kabupaten Malang)'”. Di dalam jurnal ini menjelaskan tentang hak yang dimiliki oleh seorang hakim dalam memutuskan suatu perkara yaitu hak Ex Officio, hak hakim karena jabatannya untuk memutus perkara lebih dari yang dituntut, sekalipun para pihak tidak menuntutnya. Hak ini lah yang sering digunakan hakim dalam memutuskan perkara cerai talak yang tidak pernah dihadiri oleh termohon. ${ }^{10}$

8 An Nisa Primasari, "Putusan Hakim Pengadilan Agama Nganjuk Atas Nafkah Yang Harus Suami Pada Cerai Talak (Studi Analisis Perkara No. 1839/Pdt.G/1015/PA.Ng)."( Penelitian, UIN Maulana Malik Ibrahim Malang), 2016.

9 Syaiful Annas, "Masa Pembayaran Beban Nafkah Iddah Dan Mut'ah Dalam Perkara Cerai Talak (Sebuah Implementasi Hukum Acara di Pengadilan Agama)”. 2017.

${ }^{10}$ Muhammad Aqwam Thariq, "Hak Ex Officio Hakim: Pertimbangan Hukum Hakim
Dari kelima penelitian terdahulu tersebut, disini penulis akan membahas dengan analisis yang berbeda mengenai tema tersebut yaitu 'Pembebanan mut'ah dan nafkah 'iddah pada perkara cerai talak dengan putusan verstek (Studi terhadap putusan Pengadilan Agama Kuningan

No.1436/Pdt.G/2019/PA.Kng)"'.

\section{METODOLOGI PENELITIAN}

Penelitian ini menggunakan pendekatan yuridis normatif yaitu pendekatan yang dilakukan berdasarkan bahan hukum utama dengan cara menelaah teori-teori, konsep-konsep, asas-asas hukum serta peraturan perundang-undangan yang berhubungan dengan penelitian ini. Dengan jenis penelitian yang dipakai dalam penelitian ini adalah penelitian lapangan (field research) dengan menggunakan metode pendekatan kualitatif deskriptif analisis, yaitu umumnya menggunakan strategi multi metode yaitu, observasi, wawancara, serta penelaahan dokumen yang ada satu dengan lain saling melengkapi, memperkuat, dan menyempurnakan. Adapun dalam pengambilan datanya bersumber dari data primer dan data sekunder. Sumber data primer dalam penelitian ini adalah Putusan Pengadilan Agama Kuningan No.1436/Pdt.G/2019/PA.Kng. sedangkan untuk sumber data sekunder adalah bukubuku seputar Hukum Acara Peradilan Agama maupun buku-buku yang berkaitan dengan nafkah serta penelitianpenelitian terdahulu seperti Penelitian yang relevan dengan penelitian ini. Metode yang digunakan untuk menganalisis data penelitian ini adalah deskriptif analitis dengan pola deduktif. Dimana akan digambarkan terlebih dahulu mengenai data-data yang

terhadap Pembebanan Nafkah Iddah dan Mut'ah dalam Perkara Cerai Talak Verstek Perspektif Maqashid Syariah (Kasus di Pengadilan Agama Kabupaten Malang)". 2019. 
berkaitan dengan perkara tersebut secara umum dan pertimbangan hukum hakim mengenai pembebanan mut'ah dan nafkah 'iddah serta pembebanan mut'ah dan nafkah 'iddah dalam perkara cerai talak verstek ditinjau dari Pasal 178 ayat (3) HIR. Kemudian diakhiri dengan kesimpulan yang bersifat khusus terhadap perkara putusan cerai talak verstek di Pengadilan Agama Kuningan mengenai pembebanan mut'ah dan nafkah 'iddah.

\section{KONSEP DASAR}

\section{Pengertian dan Dasar Hukum Cerai Talak}

Talak dalam istilah fikih disebut perceraian atau furqah, kata talak berarti membuka ikatan, membatalkan perjanjian, sedangkan furqah berarti bercerai, kedua istilah tersebut oleh ahli fikih diartikan sebagai perceraian suami istri. Sedangkan perceraian berasal dari kata dasar cerai yang berarti pisah dan talak. Jadi, perceraian adalah putusnya ikatan perkawinan suami dan istri yang sah dengan menggunakan lafadz talak atau semisalnya. Maka dari itu dalam keumuman masyarakat, talak dipahami sebagai sebuah perceraian/perpisahan yang terjadi antara suami dan istri. Kata talak itu sendiri sudah menjadi bahasa sehari-hari sehingga jika menyebutkan talak berarti perceraian Sebuah hadis yang sangat dikenal yang mempersoalkan talak ini ialah yang diriwayatkan oleh Abu Daud, karena illah talak dapat berubah hukumnya. ${ }^{11}$

Rasulullah bersabda :

$$
\text { أَبْغَضُ الحَلَلَلِ إِلَى اللَّهِ تَعَالَى الطَّلَقُقُ }
$$

Sesuatu perbuatan halal yang paling dibenci oleh Allah adalah thalaq/perceraian. (H.R Abu Dawud, Ibn Majah, dan Al-Hakim). ${ }^{12}$

\section{Akibat Putusnya Perkawinan}

\footnotetext{
11 Rasyid Sulaiman, Fiqh Islam (Jakarta: Attahiriyah, 1954), 366.

${ }^{12}$ Hosein Ibrahim, Fiqh Perbandingan dalam Masalah Talaq, (Jakarta: Tintamas, 1961),
}

Menurut ketentuan pasal 41 Undang-undang Nomor 1 Tahun 1974 tentang Perkawinan. Akibat putusnya perkawinan karena perceraian ialah:

a. Baik ibu atau bapak tetap berkewajiban memelihara dan mendidik anak-anaknya, sematamata berdasarkan kepentingan anak; bilamana ada perselisihan mengenai penguasaan anak-anak, Pengadilan memberi keputusannya;

b. Bapak yang bertanggung jawab atas semua biaya pemeliharaan dan pendidikan yang diperlukan anak itu; bilamana bapak dalam kenyataan tidak dapat memenuhi kewajiban tersebut, Pengadilan dapat menentukan bahwa ibu ikut memikul biaya tersebut.

c. Pengadilan dapat mewajibkan kepada bekas suami untuk memberikan biaya penghidupan dan/atau menentukan sesuatu kewajiban bagi bekas istri. ${ }^{13}$

\section{Mut'ah}

Di dalam syariat Islam mut'ah dikenal dengan pemberian dari suami terhadap istri yang telah diceraikannya. Maksud pemberian tersebut adalah untuk menyenangkan pihak isri yang telah dicerai tadi. Adapun ukuran dan jumlah pemberian sangat tergantung kepada kemampuan suami. ${ }^{14}$ Ukuran mut'ah tidak diterangkan dalam syara', mut'ah berada di antara sesuatu yang memerlukan ijtihad maka wajib dikembalikan kepada hakim sebagaimana hal hal lain yang memerlukan ijtihad. Ukuran mut'ah berbeda-beda sesuai dengan perbedaan zaman dan tempat. Mut'ah yang layak dan rasional pada suatu zaman terkadang tidak layak pada zaman lain. Demikian juga mut'ah yang layak disuatu tempat terkadang tidak layak di tempat lain.

\footnotetext{
13 Undang-undang Nomor 1 Tahun 1974 tentang Perkawinan, Pasal 41.

${ }_{14}$ Sudarsono, Pokok-Pokok Hukum Islam (Jakarta: Rineka Cipta, 2001). 227.
} 


\section{Nafkah 'Iddah}

Nafkah adalah sebagai biaya yang wajib dikeluarkan oleh seseorang terhadap sesuatu yang berada dalam tanggungannya meliputi biaya untuk kebutuhan pangan, sandang dan papan termasuk kebutuhan sekunder seperti perabot rumah tangga. Para ulama mendefinisikan 'iddah sebagi nama waktu untuk menanti kesucian seorang istri yang ditinggal mati atau diceraikan oleh suami,yang sebelum habis masa itu dilarang untuk dinikahkan. ${ }^{15}$ Jadi, Nafkah 'iddah adalah segala sesuatu yang diberikan oleh seorang suami kepada istri yang telah diceraikannya untuk memenuhi kebutuhan selama masa 'iddah, baik itu berupa pakaian, makanan maupun tempat tinggal.

\section{Macam-Macam 'Iddah}

Macam-macam iddah ditinjau dari perhitungan masanya 'iddah dibagi tiga yaitu 'iddah dengan perhitungan bulan, 'iddah dengan perhitungan suci dari haid dan 'iddah karena melahirkan. Ditinjau dari sebab terjadinya perceraian, 'iddah dapat dibagi dua yaitu 'iddah kematian dan 'iddah talak.

Ditinjau dari sebab terjadinya perceraian iddah dibagi menjadi dua macam yaitu sebagai berikut:

a. Iddah Kematian

Istri yang ditinggal mati suaminya harus menjalani 'iddah sebagi berikut:

1) Bagi istri yang tidak dalam keadaan hamil, baik sudah berkumpul dengan suaminya atau belum, iddah-nya adalah empat bulan sepuluh hari.

2) Bagi istri yang dalam keadaan hamil, 'iddah-nya adalah sampai melahirkan meskipun

15 Amiur Nuruddin dan Azhari Akmal Tarigan, Hukum Perdata Islam di Indonesia Studi Kritis Perkembangan Hukum Islamdan Fikih, UU No. 1/1974 sampai KHI, .., 240 waktu antara ditinggal mati dan melahirkan kurang dari empat bulan sepuluh hari.

b. Iddah Talak

Istri yang bercerai dengan suaminya dengan jalan talak harus menjalani masa 'iddah sebagi berikut:

1) Bila isteri yang ditalak dalam keadaan hamil, 'iddah-nya adalah sampai melahirkan kandungan, dengan ketentuanketentuan tersebut diatas, yaitu yang dilahirkan benar-benar telah berbentuk janin, meskipun lahir sebelum waktunya (prematur), bukan sekedar keguguran yang masih berupa gumpalan-gumpalan darah.

2) Istri yang masih mengalami menstruasi, 'iddah-nya adalah tiga kai suci, termasuk suci pada waktu terjadi talak, asal sebelumnya tidak dilakukan hubungan suami istari.

3) Istri yang tidak pernah atau sudah tidak dapat lagi mengalami menstruasi, iddahnya adalah tiga bulan. ${ }^{16}$

\section{Hak-Hak Perempuan dalam Masa 'Iddah}

a. Para fuqaha sepakat bahwa perempuan yang sedang dalam masa 'iddah talak raj'i berhak atas nafkah dari mantan suami. Nafkah yang dimaksud disini ialah nafkah yang diberikan sebelum terjadi perceraian. Nafkah tersebut berupa tempat tinggal, sandang dan pangan, sesuai ketentuan yang berlaku. ${ }^{17}$ Kecuali ia dianggap nusyuz (melakukan hal-hal yang dianggap "durhaka",

16 Hamid Sarong, Hukum Perkawinan Islam di Indonesia, (Banda Aceh: PeNA, 2010), 156-160.

17 Hamid Sarong, Hukum Perkawinan Islam di Indonesia,..., 162. 
yakni melanggar kewajiban taat kepada suaminya) maka ia tidak berhak apa-apa.

b. Perempuan dalam masa 'iddah akibat talak ba'in (yakni yang tidak mungkin dirujuk) apabila ia dalam keadaan mengandung berhak juga atas tempat tinggal dan nafkah seperti di atas.

c. Perempuan dalam masa 'iddah akibat talak ba'in (yakni yang tidak mungkin dirujuk) yang tidak sedang mengandung, baik akibat talak tebus (khulu') atau talak tiga, hanya berhak memperoleh tempat tinggal. Ini menurut pendapat imam Malik dan imam Syafi'i. Sedangkan menurut imam Abu Hanifah, ia berhak memperoleh nafkah dan tempat tinggal selama menjalani masa 'iddah.

d. Perempuan dalam keadaan 'iddah akibat suaminya meninggal dunia menurut sebagian ulama tidak mempunyai hak nafkah maupun tempat tinggal, mengingat bahwa harta peninggalan suaminya kini telah menjadi hak ahli waris , termasuk ia dan anakanaknya. ${ }^{18}$

\section{Putusan Verstek}

Putusan dapat dimaknai sebagai suatu pernyataan oleh hakim sebagai pejabat negara yang diberi wewenang untuk itu dan diucapkan dalam persidangan yang terbuka untuk umum dengan tujuan untuk menyelesaikan suatu perkara atau sengketa antara pihak yang berperkara. ${ }^{19}$ Dari definisi diatas dapat

18 Amiur Nuruddin dan Azhari Akmal Tarigan, Hukum Perdata Islam di Indonesia Studi Kritis Perkembangan Hukum Islamdan Fikih, UU No. 1/1974 sampai KHI,..,249-250.

19 Ahmad Mujahidin, Pembaharuan Hukum Acara Perdata Peradilan Agama dan Mahkamah Syar'iyah di Indonesia,..., 337. dipahami bahwa putusan adalah kesimpulan akhir yang diambil oleh Majelis Hakim yang diberi wewenang untuk menyelesaikan atau mengakhiri suatu sengketa antara pihak-pihak yang berperkara dan diucapkan dalam sidang terbuka untuk umum.

Putusan Verstek, yaitu putusan yang diambil dari tergugat yang tidak pernah hadir dipersidangan meskipun telah dipanggil secara resmi dan patut, tetapi gugatan dikabulkan dengan putusan di luar hadir atau verstek. Putusan verstek di luar hadir tergugat ini dijalankan bila tergugat tidak datang pada hari sidang pertama dan berikutnya. ${ }^{20}$

Putusan verstek yang mengabulkan gugatan penggugat harus memenuhi syarat-syarat berikut ini:

1. Tergugat atau para tergugat tidak datang pada hari sidang yang telah ditentukan.

2. Ia atau mereka tidak mengirimkan wakil atau kuasanya yang sah untuk menghadap dan tidak ternyata pula bahwa ketidakhadirannya itu karena sesuatu alasan yang sah.

3. Ia atau mereka telah dipanggil dengan resmi dan patut.

4. Petitum tidak melawan hak.

5. Petitum beralasan.

Beberapa syarat tersebut harus satu persatu diperiksa secara teliti, apabila persyaratan itu terpenuhi maka putusan verstek dapat dijatuhkan dengan mengabulkan gugatan penggugat. Apabila syarat 1,2 dan 3 dipenuhi, akan tetapi petitumnya melawan hak atau tidak beralasan maka walaupun perkara diputus dengan verstek tetapi gugatan ditolak. ${ }^{21}$

\section{E. PEMBAHASAN DAN ANALISIS}




\section{Pertimbangan Para Hakim mengenai Pembebanan Mut'ah dan Nafkah 'Iddah pada Perkara Cerai Talak dengan Putusan Verstek}

Dilihat dari dasar pertimbangan hakim dalam putusan No. 1436/Pdt.G/2019/PA.Kng yang mana majelis hakim dalam putusannya membebankan kepada pemohon untuk membayar mut'ah sebesar Rp. 1.000.000,- dan nafkah 'iddah berupa uang sebesar Rp. 3.000.000,- kepada termohon, sekalipun hal tersebut tidak terdapat di petitum permohonan. Dan berdasarkan hasil wawancara dengan beberapa hakim Pengadilan Agama Kuningan yaitu Bapak Drs. Ahmad Nasohah, M.H, Bapak Drs. H. Zulkifli, S.H.,M.H, dan Ibu Dra. Hj. Indah Nirmala, M.H, bahwa ada beberapa poin pertimbangan hakim di dalam membebankan mut'ah dan nafkah 'iddah dalam perkara cerai talak dengan putusan verstek yaitu :

1. Pasal 41 huruf (c) Undang-undang No 1 Tahun 1974 tentang Perkawinan, yang berbunyi "Pengadilan dapat mewajibkan kepada bekas suami untuk memberikan biaya penghidupan dan/atau menentukan sesuatu kewajiban bagi bekas isteri". Dari pasal ini walaupun istri tidak hadir dan tidak menuntut apapun baik itu mut'ah atau nafkah 'iddah dari suami, tetapi terdapat pengecualian karena hakim mempunyai hak yang dinamakan ex-officio hakim artinya hak atau kewenangan yang dimiliki hakim karena jabatannya, salah satunya adalah untuk memutus atau memberikan sesuatu yang tidak ada dalam tuntutan. Walaupun hak ex officio adalah hak yang melekat pada hakim. Penerapan hak ex officio hakim mengacu pada Pasal 41 huruf (c) Undangundang No 1 Tahun 1974 tentang
Perkawinan "Pengadilan dapat mewajibkan kepada bekas suami untuk memberikan biaya penghidupan dan/atau menentukan sesuatu kewajiban bagi bekas istri”. Karena dalam Undang-undang redaksinya adalah kata "dapat", maka hakim boleh menerapkan dan boleh tidak menerapkan hak ex officio tersebut.

2. Pasal 149 huruf (a) dan (b) Kompilasi Hukum Islam, yang berbunyi " Bilamana perkawinan putus karena talak maka bekas suami wajib : (a) memberikan mut'ah yang layak kepada bekas istrinya baik berupa uang atau benda, kecuali bekas istri tersebut qabla al dukhul; (b) memberi nafkah, maskan dan kiswah kepada bekas istri selama dalam 'iddah, kecuali bekas istri telah dijatuhi talak balin atau nusyur dan dalam keadaan tidak hamil. Dan Pasal 158 Kompilasi Hukum Islam. yang berbunyi “ mut'ah wajib diberikan oleh mantan suami dengan syarat : a) belum ditetapkan mahar bagi istri $b a^{\prime} d a$ al dukhul, b) perceraian itu atas kehendak suami. Pasal-pasal ini menunjukkan kalimat "wajib" bagi suami untuk memberikan mut'ah dan nafkah lain seperti nafkah 'iddah karena telah menceraikan istrinya. Dari pasalpasal inilah yang dijadikan bahan pertimbangan para hakim dalam membebankan mut'ah dan nafkah 'iddah meskipun pihak istri tidak memintanya karena hakim berniat mengingatkan kepada pihak suami bahwa ia mempunyai kewajiban yang harus diberikan kepada istri karena telah menceraikannya. Selain itu, dalam perkara ini majelis menganggap bahwa istri yang diceraikan tidak tergolong 
nusyuz, maka selama menjalani masa iddah istri berhak mendapatkan mut'ah dan nafkah 'iddah yang layak.

3. Peraturan Mahkamah Agung Republik Indonesia Nomor 3 Tahun 2017 tentang Pedoman Mengadili Perkara Perempuan Berhadapan dengan Hukum. Pasal menentukan bahwa untuk memberikan hak-hak perempuan pasca perceraian, maka pembayaran kewajiban akibat perceraian dapat dicantumkan dalam amar putusan dengan kalimat dibayar sebelum pengucapan ikrar talak. Bapak Drs. H. Zulkifli, S.H.,M.H dan Ibu Dra. Hj. Indah Nirmala, M.H, menjadikan PERMA ini sebagai pertimbangan hakim manakala harus membebankan mut'ah dan nafkah 'iddah kepada suami. Hakim menganggap bahwa ketidakhadiran isteri di persidangan, bisa jadi karena keterbatasan ekonomi, bisa juga karena mengurus anak jika anaknya masih kecil atau juga karena tempat pengadilan agama jauh dari kediamannya. Maka hakim menjadikan PERMA ini untuk melindungi hak-hak perempuan pasca perceraian.

4. Dalil al-Qur'an yang menunjukkan bahwa suami wajib memberikan mut'ah dan nafkah 'iddah karena telah menceraikan istrinya. Dalil al-Qur'an yang menunjukkan bahwa suami wajib memberikan mut'ah dan nafkah 'iddah karena telah menceraikan istrinya, yaitu untuk mut'ah ada pada surat al-Baqarah ayat 241 :

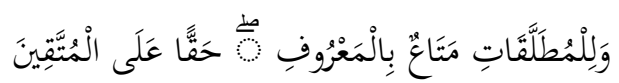

Dan bagi perempuan-perempuan yang diceraikan hendaklah diberi mut'ah menurut cara yang patut sebagai suatu kewajiban bagi orang yang bertakwa.

Tujuan disyariatkan mut'ah ialah untuk memberikan rasa bahagia dan senang kepada mantan istri. Artinya pemberian mut'ah ini di samping merupakan kewajiban agama, juga sebagai bekal istri selama masa-masa kesendiriannya tanpa suami. Sehingga majelis hakim secara ex officio memandang layak dan adil untuk membebankan mut'ah kepada pemohon sebesar sebesar Rp. 1.000.000,- yang didasari dengan memperhatikan kondisi ekonomi pemohon.

Sedangkan kewajiban untuk memberikan nafkah'iddah terdapat pada surat at-Thalaq ayat

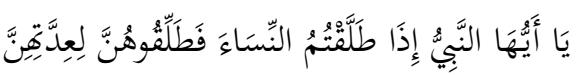

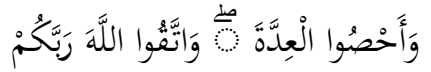

Wahai Nabi! Apabila kamu menceraikan istri-istrimu maka hendaklah kamu ceraikan mereka pada waktu dapat (menghadapi) 'iddah-nya (yang wajar) dan hitunglah waktu 'iddah itu serta bertawakal kepada Allah.

Dalam ketentuan syariat dalam masa 'iddah ini, suami masih berkewajiban untuk memberikan nafkah 'iddah kepada istri yang telah di talaknya. Maka berdasarkan pertimbangan ini, majelis hakim membebankan kepada pemohon untuk membayar nafkah 'iddah selama 3 bulan kepada termohon sebesar Rp.3.000.000,--

5. Dalam pembebanan mut'ah dan nafkah 'iddah majelis hakim melihat terlebih dahulu, apakah termohon/ istri tergolong istri yang nusyuz atau tidak. Apabila dalam pemeriksaan perkara tidak ditemukan fakta bahwa isteri/termohon tergolong istri 
yang nusyuz maka ia berhak
mendapatkan nafkah iddah.
Namun, apabila $\begin{array}{r}\text { dalam } \\ \text { ditemukan fakta }\end{array}$
persidangan ditrittermohon tergolong
bahwa istri
istri yang nusyuz, maka gugur
haknya dalam mendapatkan
nafkah iddah. Hal ini sesuai
dengan ketentuan Pasal 152
Kompilasi Hukum Islam, yang
berbunyi "Bekas istri berhak
mendapatkan nafkah iddah dari
mantan suaminya kecuali ia
nusyuz".

6. Melihat kemampuan/kesanggupan suami dari pekerjaan dan penghasilannya. Dengan melihat pekerjaan suami hakim dapat memperkirakan berapa penghasilan suami setiap bulannya, yang nantinya akan menjadi tolak ukur hakim dalam memperhitungkan berapa kadar yang seharusnya diberikan kepada mantan istrinya. Dan dilihat dari penghasilan tersebut maka hakim dengan keyakinan dan kemampuannya akan menetapkan kadar sesuai dengan asas kelayakan dan kepatutan menurut hakim itu sendiri.

Berdasarkan informasi yang peneliti peroleh dari hasil wawancara dengan hakim Pengadilan Agama Kuningan bahwa para hakim tersebut memiliki kegelisahan manakala harus membebankan mut'ah dan nafkah 'iddah pada perkara cerai talak yang tidak pernah dihadiri oleh pihak termohon/ istri. Ini kaitan nya dengan hukum progresif yang sudah dijelaskan di atas walaupun sudah ada Undang-undang atau peraturan lain yang mengatur tentang kewajiban memberikan mut'ah dan nafkah 'iddah untuk mantan istri, namun hakim tidak sepenuhnya menjadikan aturan itu sebagai pertimbangan dalam memutuskan perkarai cerai talak. Ada alasan-alasan lain yang menjadi pertimbangan hakim sebelum membebankan mut'ah dan nafkah 'iddah pada perkara cerai talak dengan putusan verstek, alasan-alasan tersebut diantaranya adalah :

1. Dalam himpunan nash dan hujjah syar'iyyah putusan Penetapan Pengadilan Agama yaitu suatu kaidah hukum mengatakan bahwa seseorang yang dipanggil hakim (Pengadilan) tidak datang, ia dipandang sebagai zalim dan tidak ada hak baginya.

2. Bahwa penggunaan hak ex-officio berdasarkan pasal 41 huruf (c) Undang-undang Nomor 1 Tahun 1974 itu lemah.

3. Dari segi efektivitas bahwa pembayaran mut'ah dan nafkah 'iddah sebelum pengucapan ikrar talak harus benar-benar sudah dibayarkan.

4. Pada saat ikrar talak termohon tidak hadir dan pemohon membayar mut'ah dan nafkah 'iddah yang dititipkan pada pihak pengadilan maka hal ini akan menyulitkan pengadilan dalam hal eksekusinya.

5. Melindungi hak-hak perempuan itu tidak harus dengan diberikannya mut'ah dan nafkah 'iddah karena telah diceraikan oleh suaminya, tetapi hak-hak itu diberikan secara proposional artinya jika dilihat dari segi fikih bahwa kita harus dapat menempatkan sesuatu berdasarkan tempatnya.

6. Terdapat juga beberapa kasus istri tidak mau menerima pemberian mut'ah dan nafkah 'iddah dari mantan suami

Relevansi Pembebanan Mut'ah dan Nafkah 'Iddah pada Perkara Cerai Talak dengan Putusan Verstek Studi Putusan No.1436/Pdt.G/2019/PA.Kng 


\section{apabila ditinjau dari Pasal 178 ayat (3) HIR}

Pada Pasal 178 ayat (3) HIR yang berbunyi: "Hakim dilarang menjatuhkan putusan atas hal-hal yang tidak diminta atau mengabulkan lebih daripada yang digugat". Pasal tersebut sesuai dengan salah satu asas umum peradilan agama yaitu ultra petitum partem yang artinya hakim tidak boleh menjatuhkan putusan atas perkara yang tidak diminta atau hukum mengabulkan lebih dari yang dituntut. Kaitannya dengan putusan No.1436/Pdt.G/2019/PA.Kng yaitu perkara cerai talak dengan putusan verstek, yang mana pihak termohon tidak pernah menghadiri persidangan sekalipun, tetapi di dalam putusan nya ada penambahan dengan menghukum pemohon agar memberikan kepada termohon mut'ah berupa uang sejumlah Rp. 1.000.000,- (satu juta rupiah) dan nafkah selama 'iddah sejumlah $\mathrm{Rp}$. 3.000.000,- (tiga juta rupiah) kepada Termohon. Padahal hai itu tidak ada dalam tuntutan pemohon. Sehingga hal ini tidak sesuai dengan pasal 178 ayat (3) karena hakim telah mengabulkan lebih dari yang diminta.

Pembebanan mut'ah dan nafkah iddah ini dianggap tidak termasuk ke dalam ultra petitum sepanjang hal-hal yang dibebankan masih berkaitan dengan perkara tersebut. Dan pasal 178 ayat (3) HIR ini termasuk ke dalam pasal yang masih bersifat umum, sedangkan Pasal 41 (c) Undang-undang Nomor 1 tentang Perkawinan yang merupakan lex spesialis atau bersifat khusus, sehingga hakim karena jabatannya (secara ex officio) dapat mewajibkan kepada mantan suami untuk memberikan biaya penghidupan dan atau menentukan suatu kewajiban bagi mantan istri. Hal tersebut dimaksudkan untuk terwujudnya perceraian yang adil dan ihsan, di samping untuk mewujudkan peradilan yang sederhana, cepat dan biaya ringan. Penggunaan hak ex officio sebenarnya diterapkan hakim Pengadilan Agama didasarkan pada konsep kemaslahatan, saat hak ex officio tersebut diterapkan untuk memberikan hak-hak yang dimiliki mantan istri dari mantan suami, pemberian tersebut dapat digunakan mantan istri untuk mencukupi kebutuhan sehari-hari setelah terjadi perceraian.

\section{F. KESIMPULAN}

Dari pembahasan yang telah dikemukakan diatas, maka penulis dapat menarik sebuah kesimpulan yang terkait dengan judul Penelitian ini yaitu tantang Pembebanan Mut'ah dan Nafkah 'Iddah pada Perkara Cerai Talak dengan Putusan Verstek (Studi terhadap Putusan Pengadilan Agama Kuningan No.1436/Pdt.G/2019/PA.Kng.

Kesimpulannya adalah sebagai berikut:

1. Pertimbangan para hakim mengenai pembebanan mut'ah dan nafkah 'iddah pada perkara cerai talak dengan putusan verstek dengan mempertimbangkan: a) secara yuridis yaitu berdasarkan Undangundang No 1 Tahun 1974, Kompilasi Hukum Islam, Peraturan Mahkamah Agung Republik Indonesia. b) berdasarkan dalil al-Qur'an tentang kewajiban memberikan mut'ah dan nafkah 'iddah kepada mantan istri. c) berdasarkan kondisi sosial para pihak.

Hakim memiliki pandangan lain diliat dari segi hukum progresif sebelum membebankan mut'ah dan nafkah 'iddah pada perkara cerai talak verstek, yaitu sebagai berikut: 1) berdasarkan kaidah hukum 2) Penggunaan hak ex-officio yang lemah; 3) adanya kasus dimana pemohon tidak benar-benar memberikan kewajibannya kepada mantan istri; 4) adanya beban titipan dari pihak suami kepada pengadilan; 5) Melindungi hak-hak perempuan sesuai dengan tempatnya; 6) Adanya kasus dimana kasus istri tidak mau 
menerima pemberian dari mantan suami

2. Relevansi pembebanan mut'ah dan nafkah 'iddah pada perkara cerai talak dengan putusan verstek studi putusan

No.1436/Pdt.G/2019/PA.Kng apabila ditinjau dari pasal 178 ayat (3) HIR yaitu a) dianggap tidak bertentangan sepanjang hal-hal yang diminta hakim masih berkaitan erat dengan perkara yang ditangani. b) hakim memiliki kebebasan untuk menggunakan hak nya yaitu hak exofficio hakim.

\section{DAFTAR PUSTAKA}

Annas, Syaiful, "Masa Pembayaran Beban Nafkah Iddah Dan Mut'ah Dalam Perkara Cerai Talak (Sebuah Implementasi Hukum Acara di Pengadilan Agama)”. 2017

Harahap, M. Yahya, Hukum Acara Perdata tentang Gugatan, Persidangan, Penyitaan, Pembuktian, dan Putusan Pengadilan, Jakarta: Sinar Grafika, 2017

Ibrahim, Hosein, Figh Perbandingan dalam Masalah Talaq, Jakarta: Tintamas, 1961

Kompilasi Hukum Islam, 2016, Bandung: Fokusindo Mandiri

Maulana, Ade Ilma, "Pemberian Nafkah 'Iddah Dan Mut'ah Pada Perkara Cerai Talak Di Pengadilan Agama Sungguminasa Kelas $1 B^{\prime}$ Penelitian S1 UIN Alauddin Makassar, 2018

Mujahidin, Ahmad, Pembaharuan Hukum Acara Peradilan Agama, Bogor: Ghalia Indonesia, 2012

Mujahidin, Ahmad, Pembaharuan Hukum Acara Perdata Peradilan Agama dan Mahkamah Syar'iyah di
Indonesia, Jakarta: Ikatan Hakim Indonesia IKAHI, 2008

Nuruddin, Amiur dan Azhari Akmal Tarigan, Hukum Perdata Islam di Indonesia (Studi Kritis Perkembangan Hukum Islam dan Fiqih, UU No 1/1974 sampai KHI), Jakarta : Kencana, 20

Pradhika, Muhlifa Nur, "Penetapan Kadar Nafkah 'Iddah Dan Mut'ah Oleh Hakim Pada Cerai Talak Di Pengadilan Agama Salatiga (Studi Putusan Cerai Talak Tahun 2017)", Penelitian S1 IAIN Salatiga, 2018

Primasari, An Nisa, "Putusan Hakim Pengadilan Agama Nganjuk Atas Nafkah Yang Harus Suami Pada Cerai Talak (Studi Analisis Perkara No. 1839/Pdt.G/1015/PA.Ng)", Penelitian S1 UIN Maulana Malik Ibrahim Malang, 2016

R. Suesilo, RIB/HIR dengan Penjelasan, (Politea: Bogor)

Sarong, Hamid, Hukum Perkawinan Islam di Indonesia, Banda Aceh: PeNA, 2010

Sudarsono, Pokok-Pokok Hukum Islam, Jakarta: Rineka Cipta, 2001

Sulaiman, Rasyid, Fiqh Islam, Jakarta: Attahiriyah, 1954

Syarifuddin, Amir, Hukum Perkawinan Islam di Indonesia, Jakarta: Prenada Media, 2006

Thariq, Muhammad Aqwam, "Hak Ex Officio Hakim: Pertimbangan Hukum Hakim terhadap Pembebanan Nafkah Iddah dan Mut'ah dalam Perkara Cerai Talak Verstek Perspektif Maqashid Syariah (Kasus di Pengadilan Agama Kabupaten Malang)". 2019

Undang-undang Nomor 1 Tahun 1974 tentang Perkawinan 